\title{
Thermal Efficiency of a Hybrid Photovoltaic-thermal Chimney Integrated into a Building
}

\author{
Yawovi Nougbléga*, Kodjo Kpode, Kokou N’Wuitcha, Malgolmèèna Banna \\ Laboratory on Solar Energy, Group of Energetic and Transfer Phenomenon, University of Lomé, Lomé, Togo
}

Email address:

nycogl@yahoo.fr (Y. Nougbléga)

${ }^{*}$ Corresponding author

\section{To cite this article:}

Yawovi Nougbléga, Kodjo Kpode, Kokou N'Wuitcha, Malgolmèèna Banna. Thermal Efficiency of a Hybrid Photovoltaic-thermal Chimney Integrated Into a Building. American Journal of Modern Physics. Vol. 8, No. 4, 2019, pp. 50-65. doi: 10.11648/j.ajmp.20190804.11

Received: August 12, 2019; Accepted: September 2, 2019; Published: September 19, 2019

\begin{abstract}
The solar photovoltaic-thermal energy, it is a combination of Photovoltaic (PV) and solar thermal components integrated into one system and enables to generate electricity and heat simultaneously. The solar chimney can generate air flow through the living space of the building to provide cooling. Hence, there is a greater interest to study the mixed convection in the hybrid Photovoltaic-Thermal chimney integrated into buildings for natural room ventilation for thermal comfort. The thermal efficiency has been studied by analysing numerically the mixed convection in the hybrid photovoltaic-thermal chimney integrated into the building in the present paper. The stream fucntion-vorticity formulation with a finite difference numerical discretization solution scheme have been adopted. The system of algebraic governing equations is solved by Thomas algorithm method. The aim of the present paper is to study and to predict the dynamic fields and particularly of the mass flow rate of the air thermosiphon drawing in the hybrid Photovoltaic-Thermal chimney integrated into a building for passive cooling in the room. The effects of the governing parameters, particularly Grashof number $\left(10^{3} \leq \mathrm{Gr} \leq 10^{6}\right)$, that depends of the solar radiation intensity in the region, the mass flow rate of the inlet fresh air $\left(0.001 \mathrm{Kg} . \mathrm{s}^{-1} \leq \mathrm{D}_{\mathrm{m}} \leq 0.3 \mathrm{Kg} . \mathrm{s}^{-1}\right)$, the integrated chimney width on fluid flow and the heat transfer characteristics are studied in detail. Passive cooling and the electrical efficiency of the PV solar cells are increasing function of the intensity of the inlet air flow. Due to the possible reduction of cooling loads with the insertion of the photovoltaic cells plate into the chimney integrated into the building. The numerical simulation has been conducted to determine heat transfer, mass flow rate trough the chimney exit, solar cells PV efficiency and the effect of design parameters of the room and the integrated hybrid Photovoltaic-Thermal chimney to make the bioclimatic building energy autonomy. The outlet velocity, streamlines, isotherms, Nusselt number along the active walls, and the mass flow rate are plotted versus the above controlling parameters.
\end{abstract}

Keywords: Numerical Study, Mixed Convection, Integrated Solar Chimney, Passive Cooling, Thermal Comfort

\section{Introduction}

The building sector is responsible for nearly $40 \%$ of national energy consumption and $25 \%$ of greenhouse gas emissions in developed countries [1]. Meanwhile, heating, cooling and air conditioning are parts of the major energy consumption in a building. Significant strides have been made which resulted in the development of alternatives for building air conditioning systems and technologies.

Natural ventilation caused by the pressure difference between the inlet and the outlet of the building envelopes is commonly used for cooling and air conditioning. But, the use of innovative technology, including renewable energy and ventilation of a building is a simple, cheap, and energy saving method of achieving acceptable thermal comfort and indoor air quality for occupants. Night ventilation, wind towers, Trombe walls and solar chimneys are the main natural ventilation techniques [2].

In the recent ingenious practices, the ventilation could be dominated by the thermal buoyancy because the outdoor air will enter the building via the ventilation openings of the rooms and will exit though a Hybrid Photovoltaic-Thermal chimney to evacuate hot and polluted air. This Hybrid Photovoltaic-Thermal (PV/T) is a combination of Photovoltaic and solar thermal component integrated into one system capable of producing both electrical and thermal energy simultaneously [3]. The effect of the air flow induced by free convection behind the photovoltaic panels has been 
studied by Brinkworth et al. [4]; they found that the air flow induced by buoyancy forces can reduce the module's temperature by $20 \mathrm{~K}$. Then Yang et al. [5] built a test rig of a photovoltaic-wall and photovoltaic-roof for validation of their simulation model.

Mixed convection in ventilated cavities has thus received sustained attention, due to the importance of the phenomenon in many technological processes, such as the design of solar collectors, thermal design of buildings, air conditioning, and recently, the cooling of electronic circuit boards [6]. In ventilated enclosures, the interaction between the externally forced stream and the buoyancy driven flow induced by buoyancy forces could lead to complex flow structures.

In the literature, many experimental and theoretical studies conducted on simple solar and Photovoltaic-Thermal chimneys have proved the efficiency of the natural air draught in solar chimneys canals [7-10] and have showed that the temperature and the flow patterns depend strongly system parameters as chimney gaps, temperature and solar heat flux on plates. Particularly, the air flow rates vary in function of the inclination angles and are maximum for vertical chimneys canals.

A literature review of the subject shows that many authors have studied mixed convection in ventilated enclosures, [1115]. A part from studies on Trombe wall that sometime take into account the air flow inside buildings; most of the studies are related to standalone channels not coupled to an enclosure room [16-22]. Meanwhile, these previous studies had a weakness process, where the plates are constantly maintained at the fixed temperature, hence this assumption is not realistic.

From where we do the present study that the plates of the hybrid Photovoltaic-Thermal chimney integrated into the building where the plates are subjected to the heat flux of the solar radiation and consequentely the thermal and dynamic fields evolve in the time and the space until to attain the steady state. Hence the aim of the present paper is to study numerically a mixed convection problem in a vertical ventilated and heated hybrid Photovoltaic-Thermal chimney integrated into a building. In this analysis, the forced flow enters the room through an inlet opening located near the lower part of the left insulated vertical adiabatic wall and leaves from the chimney integrated to the room. This kind of ventilation supports a double interaction between the buoyancy- induced flow and the forced flow. In the lower part of the room, the forced flow injected into the room promotes the natural convection motion. A computational fluid dynamics (CFD) technique was combined with the thermal model to evaluate the predicted air movement in the room and in the chimney. A numerical simulation has been conducted to determine heat transfer, flow rate, solar cells PV efficiency and the effect of design parameters of the room and the integrated hybrid Photovoltaic- Thermal chimney. This innovation makes the bioclimatic building energy autonomy.

\section{Mathematical Formulation}

\subsection{Physical Model and Governing Equations}

The geometrical configuration deals with a simple room with length $L$ and height $h_{1}$ mounted on one side of a vertical parallel-plate chimney. The channel is designed as a solar collector with plate separation $d$ and height $h_{2}$. The hybrid Photovoltaic-Thermal collector is composed of five elements: the front glass cover, the semi-transparent photovoltaic cells (PV), air flow, absorber plate and back adiabatic wall.

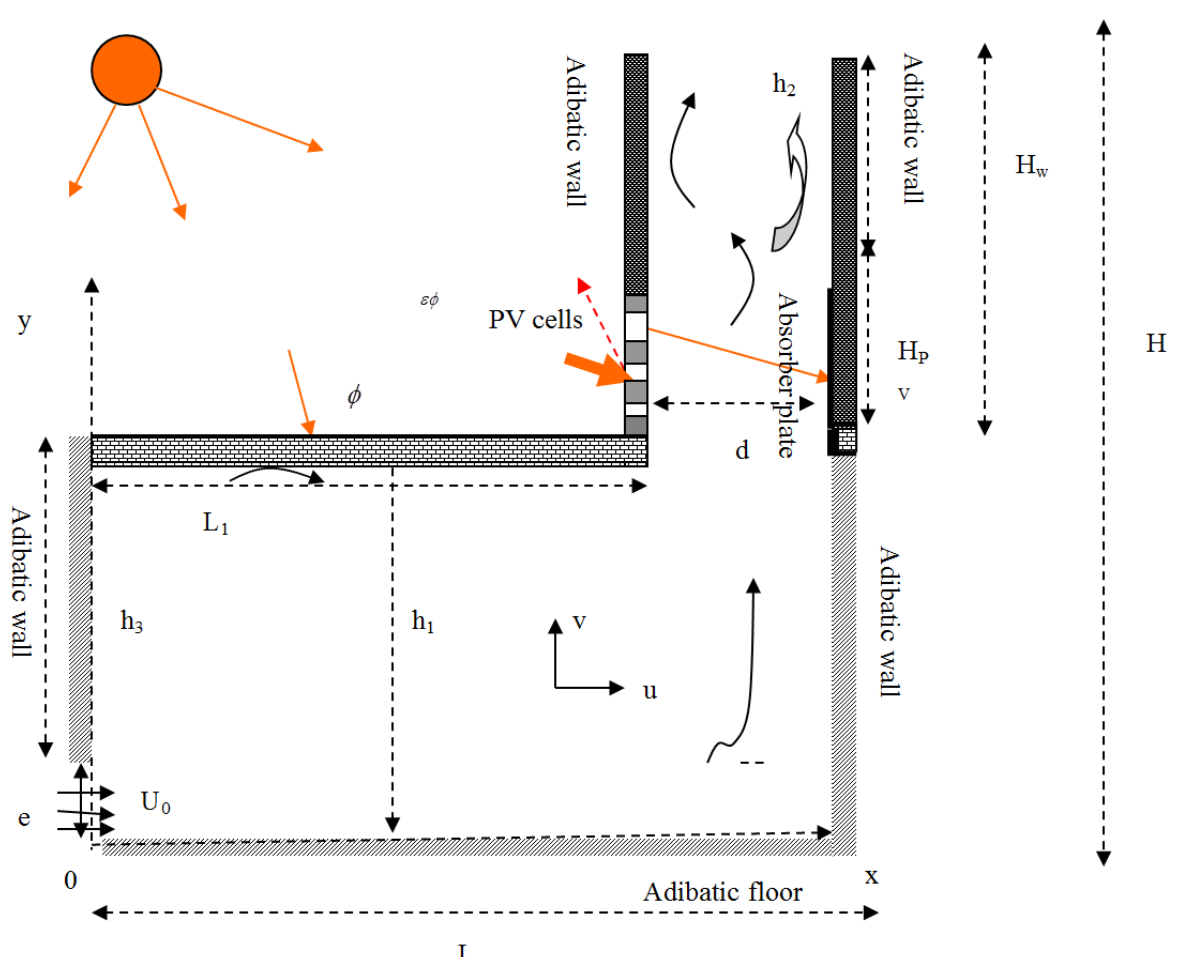

Figure 1. Physical model. 
The collector acts as an exhaust fan by sucking the room air and venting it out during sunshine hours. In the system, the PV panel absorbed the incident solar radiation and transfers heat to the air in the gap by convection and radiation phenomena. The back wall temperature rises and in turn, together with the PV module, heats the air in the gap. The upper surface and the left side wall of the room as well as the glass cover are heated by non uniform daily solar radiation flux except the back wall of the chimney; the right side wall and the floor of the room are assumed to be perfectly insulated and adiabatic. The physical system is sketched in Figure 1.

The following assumptions are used in the mathematical formulation of transfer equations:

a. The upward natural convection flow is assumed to be incompressible and laminar;

b. The physical proprieties of air are considered a constant function of temperature;

c. The multiple reflections and transmissions between the components (particularly between the photovoltaic cells and the front glass) and the radiation exchange of the PV cells to the glass are considered negligible. Taken into account these effects introduce numerous terms that are difficult to determine and to measure [23]. A very good study of these different effects was performed by Krauter et al. [24];

$\mathrm{d}$. Because the physical system is wide along the coordinate, a 2D approximation is feasible.

The non dimensional set of the governing equations

$$
\Psi=\frac{\psi}{u_{0} d} ; \omega=\frac{\Omega d}{u_{0}} ; \theta=\frac{\lambda\left(T-T_{a}\right)}{\varphi d} ; \operatorname{Re}=\frac{\rho u_{0} d}{\mu} ; G r=\frac{g \beta \varphi d^{4}}{\lambda v^{2}}
$$

\subsection{Initial and Boundary Conditions}

Through the introduction of the non dimensional parameters into the physical boundary conditions illustrated in figure 1, the following non dimensional boundary conditions are obtained:

$$
\theta=0 ; U=V=\omega=\Psi=0 \text { at } \tau=0
$$

At $\tau \succ 0$

The boundary conditions, associated with the problem are as follows:

At the inlet of the room:

$$
\begin{gathered}
X=0 \text { and } 0 \leq Y \leq D: \theta=0 ; V=0 ; U=1 ; \omega=0 ; \Psi=Y \\
X=0 \text { and } D \leq Y \leq F: U=V=\Psi=0 ;\left.\frac{\partial \theta}{\partial X}\right|_{X=0}=0 ; \omega=-\left.\frac{\partial^{2} \Psi}{\partial X^{2}}\right|_{X=0} \\
Y=0 \text { and } 0 \leq X \leq S: U=V=\Psi=0 ;\left.\frac{\partial \theta}{\partial Y}\right|_{Y=0}=0 ; \omega=-\left.\frac{\partial^{2} \Psi}{\partial Y^{2}}\right|_{Y=0} \\
Y=F \text { and } 0 \leq X \leq K: U=V=\Psi=0 ;\left.\frac{\partial \theta}{\partial Y}\right|_{Y=F}=1 ; \omega=-\left.\frac{\partial^{2} \Psi}{\partial Y^{2}}\right|_{Y=F}
\end{gathered}
$$

At the outlet of the chimney: 
If $V(X, A) \geq 0$ and $\vec{V}(X, A) \cdot \vec{n} \succ 0$

$$
Y=A \text { and } K \leq X \leq S: U=0 ;\left.\frac{\partial \theta}{\partial Y}\right|_{Y=A}=\left.\frac{\partial V}{\partial Y}\right|_{Y=A}=\left.\frac{\partial \omega}{\partial Y}\right|_{Y=A}=\left.\frac{\partial \Psi}{\partial Y}\right|_{Y=A}=0
$$

If $V(X, A) \leq 0$ and $\vec{V}(X, A) \cdot \vec{n} \prec 0$

$$
\begin{gathered}
Y=A \text { and } K \leq X \leq S: U=\theta=0 ;\left.\frac{\partial V}{\partial Y}\right|_{Y=A}=\left.\frac{\partial \omega}{\partial Y}\right|_{Y=A}=\left.\frac{\partial \Psi}{\partial Y}\right|_{Y=A}=0 \\
X=K \text { and } F \leq Y \leq G_{P V}: U=V=\Psi=0 ; \omega=-\left.\frac{\partial^{2} \Psi}{\partial X^{2}}\right|_{X=K} ;\left.\frac{\partial \theta}{\partial X}\right|_{X=K}=\left(\eta_{e l}-\tau_{g l} \alpha_{P V}\right)-\left(\frac{q_{r P V, a b s}}{\varphi}\right) \\
X=K \text { and } G_{P V} \leq Y \leq A: U=V=\Psi=0 ; \omega=-\left.\frac{\partial^{2} \Psi}{\partial X^{2}}\right|_{X=K} ;\left.\frac{\partial \theta}{\partial X}\right|_{X=K}=0 \\
X=S \text { and } 0 \leq Y \leq F: U=V=\Psi=0 ; \omega=-\left.\frac{\partial^{2} \Psi}{\partial X^{2}}\right|_{X=S} ;\left.\frac{\partial \theta}{\partial X}\right|_{X=S}=0 \\
X=S \text { and } F \leq Y \leq G_{P V}: U=V=\Psi=0 ; \omega=-\left.\frac{\partial^{2} \Psi}{\partial X^{2}}\right|_{X=S} ;\left.\frac{\partial \theta}{\partial X}\right|_{X=S}=\left(\tau_{g l} \alpha_{P V} \alpha_{a b s}\right)-\left(\frac{q_{r a b s, P V}}{\varphi}\right) \\
X=S \text { and } G_{P V} \leq Y \leq A: U=V=\Psi=0 ; \omega=-\left.\frac{\partial^{2} \Psi}{\partial X^{2}}\right|_{X=S} ;\left.\frac{\partial \theta}{\partial X}\right|_{X=S}=0
\end{gathered}
$$

Where

$$
q_{r P V, a b s}=\sigma \frac{\left(T_{P V}^{4}-T_{a b s}^{4}\right)}{\left(\frac{1}{\varepsilon_{P V}}+\frac{1}{\varepsilon_{a b s}}-1\right)} ; q_{r a b s, P V}=\sigma \frac{\left(T_{a b s}^{4}-T_{P V}^{4}\right)}{\left(\frac{1}{\varepsilon_{P V}}+\frac{1}{\varepsilon_{a b s}}-1\right)}
$$

The main engineering objective is the evaluation of heat transfer through PV cell modules and heated walls. These are well illustrated by the Nusselt number. Thus the local Nusselt number on the front side plate and the inner plate of the back cover of the chimney are given as follows:

$$
\begin{aligned}
& N u_{P V, M}(Y)=\frac{\varphi d}{\lambda\left(T_{P V, W}(K, Y)-T_{a}\right)}=\frac{1}{\theta_{P V, W}(K, Y)} ; X=K \text { and } F \leq Y \leq A \\
& N u_{a b s, M}(Y)=\frac{\varphi d}{\lambda\left(T_{a b s, W}(S, Y)-T_{a}\right)}=\frac{1}{\theta_{a b s, W}(S, Y)} ; X=S \text { and } F \leq Y \leq A
\end{aligned}
$$

The heat exchange on the upper horizontal wall of the room is evaluated by using the local Nusselt number given as follows:

$$
N u_{L 1}(X)=\frac{\varphi d}{\lambda\left(T(X, F)-T_{a}\right)}=\frac{1}{\theta(X, F)} ; Y=F \text { and } 0 \leq X \leq K
$$

The electrical efficiency of the solar PV cells is given as follows:

$$
\eta_{e l}=\eta_{r e f}+\beta_{P V}\left(\bar{T}_{P V}-298\right)+\gamma \log \left(\frac{\varphi}{1000}\right)
$$




$$
\bar{T}_{P V}=\frac{1}{h_{P V}-h_{1}} \int_{h_{1}}^{h_{0}} T_{P V}\left(L_{1}, y\right) d y
$$

The mass flow rate at the outlet of the chimney is expressed:

$$
\dot{m}=\rho u_{0} \int_{K}^{S} V(X, A) d X
$$

Where $\bar{T}_{P V}$ is the average absolute temperature of the solar PV cells plate.

\subsection{Numerical Procedure}

The differential governing equations, (1-3), were discretized using a finite difference technique. The first and second derivatives of the diffusive terms were approached by central differences while a second order upwind scheme was used for the convective terms in order to prevent possible instabilities frequently encountered in mixed convection problems. The integration of equations (2-3) with associate boundary conditions was performed by the Thomas algorithm. The non-linearity and the perfectly coupling of the governing equations need under relaxation to ensure the convergence. At each time step, the vorticity equation, equation (2), Poisson equation, equation (4), and the energy equation, equation (3) were respectively treated via the Point Successive Under-Relaxation method (PSUR) with an optimum under-relaxation coefficient equal to 0.8 for the uniform grid $(101 \times 101)$ adopted in the present study. The vorticity computational formula of Woods [25] for approximating the wall vorticity was used: $\omega_{w}=\frac{1}{2} \omega_{w+1}-\frac{3}{\Delta n^{2}}\left(\Psi_{w+1}-\Psi_{w}\right)$, where $\Psi_{w}$ and $\Psi_{w+1}$ are stream function values at the points adjacent to the boundary wall; $\mathrm{n}$ is the outward drawn normal abscise on the boundary wall. Convergence of iteration for a stream function solution is obtained at each time step. The following criterion is employed to check for a steady-state solution. Convergence of solutions is assumed when the relative error for each variable between consecutive iterations is below the convergence criterion $\varepsilon$ such that $\sum\left|\frac{\left(\Phi_{i, j}^{k+1}-\Phi_{i, j}^{k}\right)}{\Phi_{i, j}^{k+1}}\right| \prec 10^{-5}$; where $\Phi$ stands for $\Psi, \theta, \omega$; $k$ refers to time and $i$ and $j$ refer to space coordinates. The time step used in the computations is $2.5 .10^{-5}$. Grid independency solutions are assured by comparing different grid meshes for the highest Grashof and Reynolds numbers used in this work $\left(\mathrm{Gr}=10^{6}\right.$ and $\mathrm{Re}=200)$, table 1 .

Table 1. Grid independence test.

\begin{tabular}{llllll}
\hline Stage & gridsize & $\boldsymbol{\theta}_{\boldsymbol{P} \boldsymbol{V} \text { max }}$ & change (\%) & NuSPvoy & change (\%) \\
\hline Fixed M=101 & $81 \times 101$ & 0.0700 & - & 21.0088 & - \\
N varied & $101 \times 101$ & 0.0705 & 0.05 & 20.9954 & 1.34 \\
& $121 \times 101$ & 0.0707 & 0.07 & 20.9853 & 1.01 \\
Fixed N=101 & $101 \times 81$ & 0.0712 & - & 20.9807 & - \\
M varied & $101 \times 101$ & 0.0705 & 0.07 & 20.9954 & 1.47 \\
& $101 \times 121$ & 0.0701 & 0.04 & 20.9621 & 3.33 \\
\hline
\end{tabular}

\section{Results and Discussion}

\subsection{Validation}

In the objective to test the computer code developed in this study, the problem of buoyancy-driven flow in a square cavity that has differentially heated vertical walls and adiabatic horizontal walls is studied. Very good agreement is obtained between the test problem solution and benchmark solutions of Wam et al. [26] work. Where a square enclosure having two differentially heated vertical walls and adiabatic horizontal walls with no slip boundary conditions applied to all the walls. The Rayleigh number, Ra was set at $10^{4}$. The numerically predicted values of streamlines and isotherms together with benchmark results are shown in figure 2 .

\subsection{Flow Visualization}

The Aspect Ratio $(\mathrm{S}=\mathrm{L} / \mathrm{d}$ ) equal to 5 on the flow structure and temperature distribution for various values of Reynolds number $\mathrm{Re}$ is shown in Figure 3. The streamlines and the isotherms are presented for steady state flows obtained for a fixed Raleigh number $\mathrm{Ra}=10^{4}$, and Reynolds number values ranging between 20 and 200. For the fixed $\mathrm{Re}=20$, the analysis of the streamlines in figure 3 reveals a back flow phenomenon in the integrated chimney. 
Wam

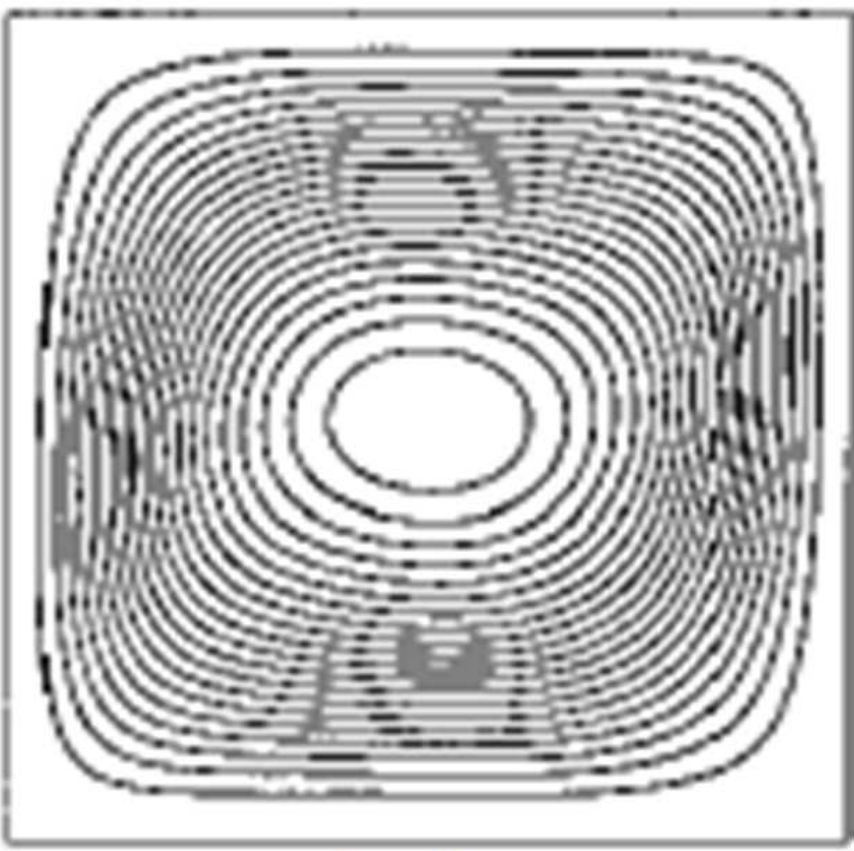

Streamlines

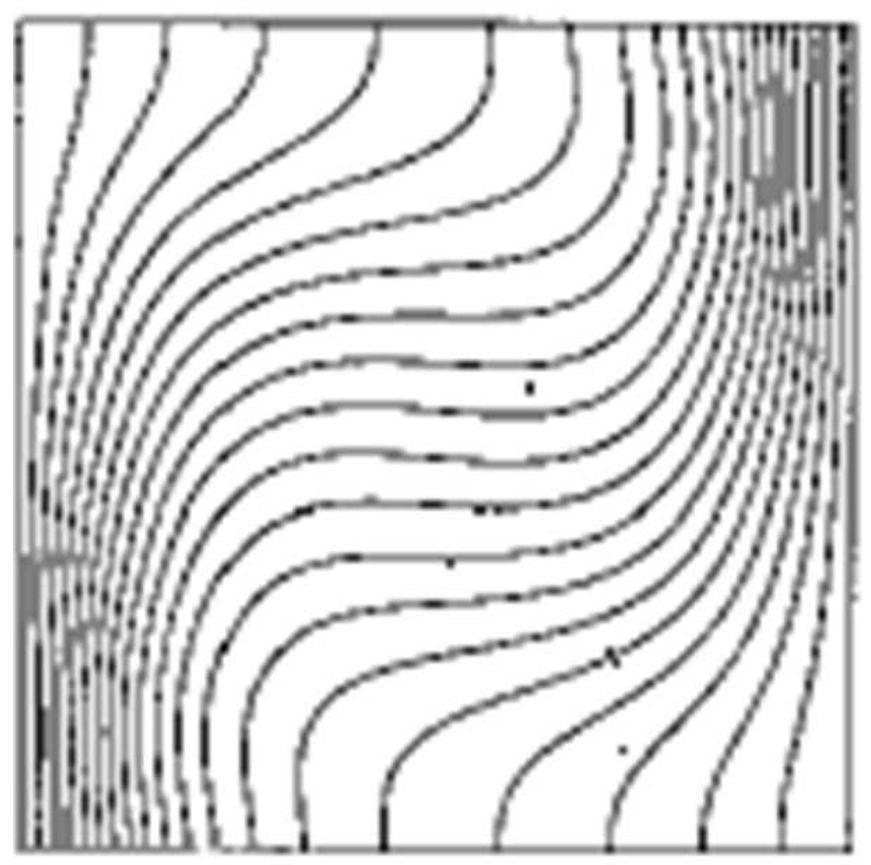

Isotherms
Present work
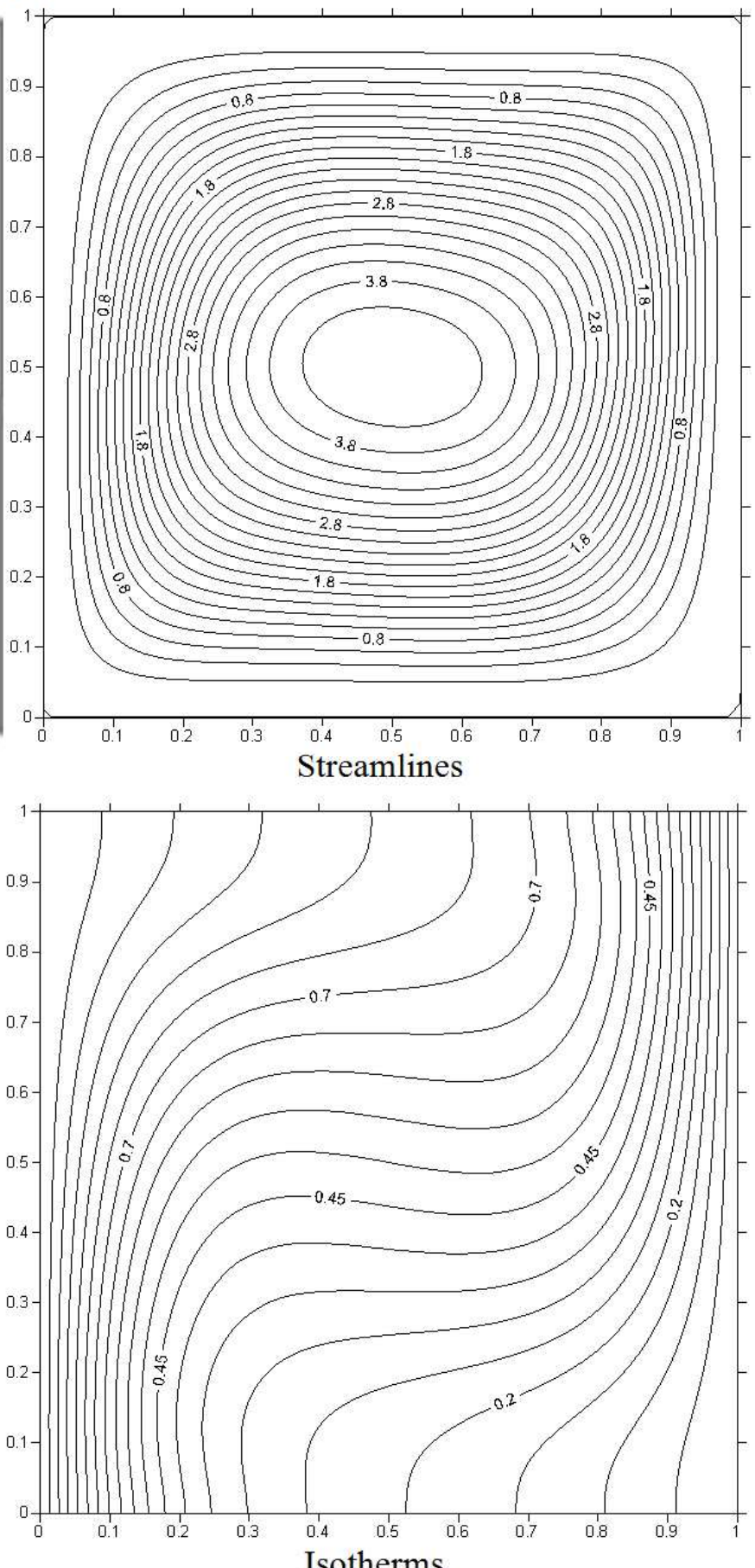

Isotherms

Figure 2. Comparison of the streamlines and isotherms.

But the recirculation cells gradually decrease for an increasing Reynolds number. It means that the forced and the natural convection effects are simultaneously present in the room and the chimney. One can observe the thermosiphon drawn of the coolant fluid. The fluid flow illustrated in the figure 3 for different values of Reynolds number indicated the permanent presence of the big closed cells in the room near the upper horizontal heated wall and prevents the free circulation of the imposed flow characterized by the open lines. The corresponding isotherm plots are presented for increasing Reynolds number at the inlet opening size, the isotherm patterns are much bifurcated, and it means that the manifestation of the mixed convection effects is established in the room and in the integrated chimney. This tendency justifies that mixed convection is the real mode of heat transfer which decreases the temperature of the PV cells in the integrated hybrid photovoltaic-chimney and is able to provide the best electrical efficiency. 

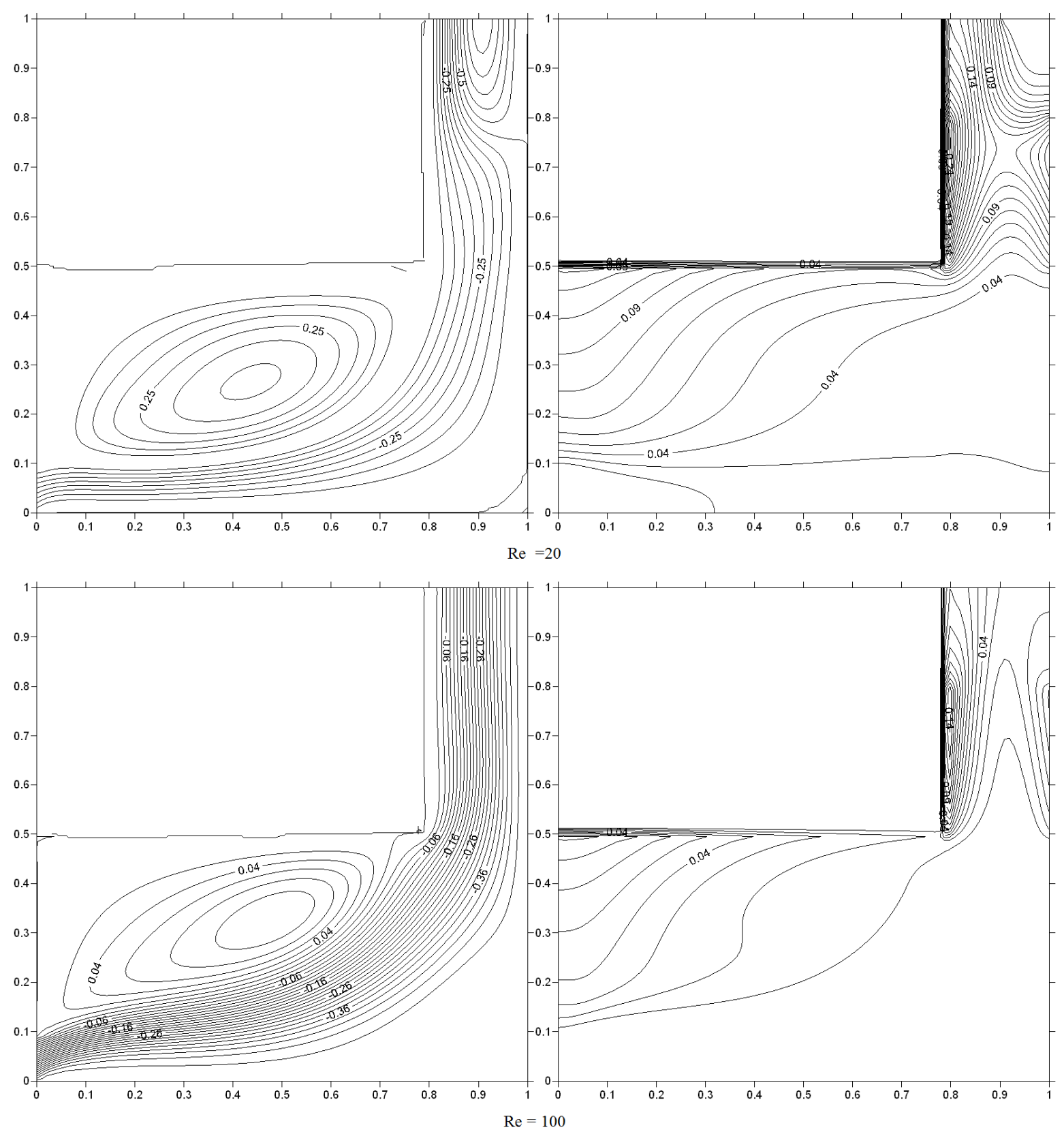

Figure 3. Streamline and isotherm patterns in the enclosure.

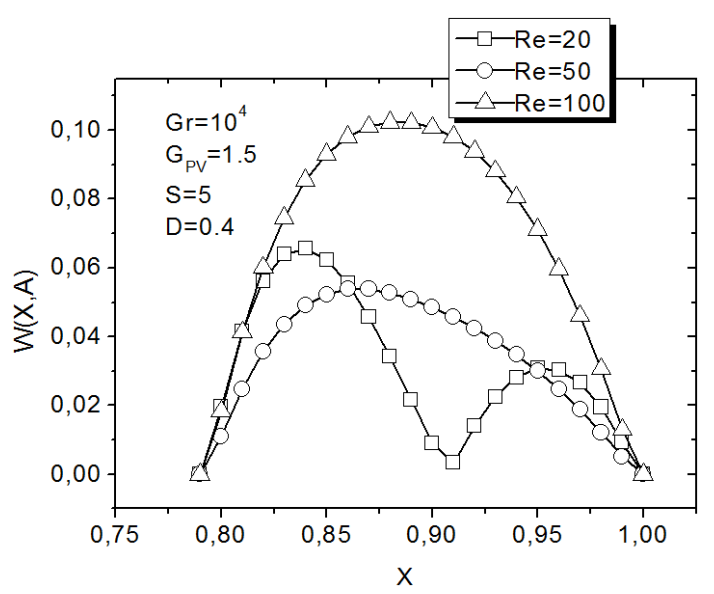

Figure 4. Outlet velocity for various Reynolds numbers.
In fact, the upper horizontal heated wall imposes a clockwise circulation in the room. Its existence is due only to the real effect of natural convection. The isotherm field indicates that the lower part of the room, (far from the heated horizontal wall) is at ambient temperature. By increasing Re the more intense is the forced flow in the room, the more important is its positive effect on natural convection flow in the lower part of the room. This tendency is visible in figure 3 for $\operatorname{Re}=100$. It is very clear in this figure that the increasing of the $\mathrm{Re}$ is accompanied by a reduction in the size and the intensity of the upper big closed cells in favor of the open lines. The outlet airflow velocity at the exit of the integrated hybrid photovoltaic- thermal chimney increases and reaches a maximal value at the middle of the chimney before decreasing to attain the minimal value near the back 
wall as shown in figure 4. This figure shows that the outlet velocity increases when the Reynolds number increases. The figure 5 indicates that the local Nusselt number along the front glass plate (the heated PV cells plate and the adiabatic wall) and the upper horizontal heated wall is increasing when the Reynolds number increases.

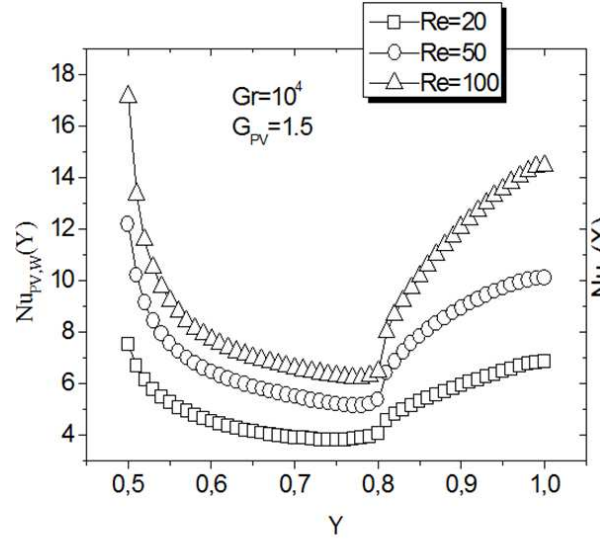

(a) PV cells plate and adiabatic wall

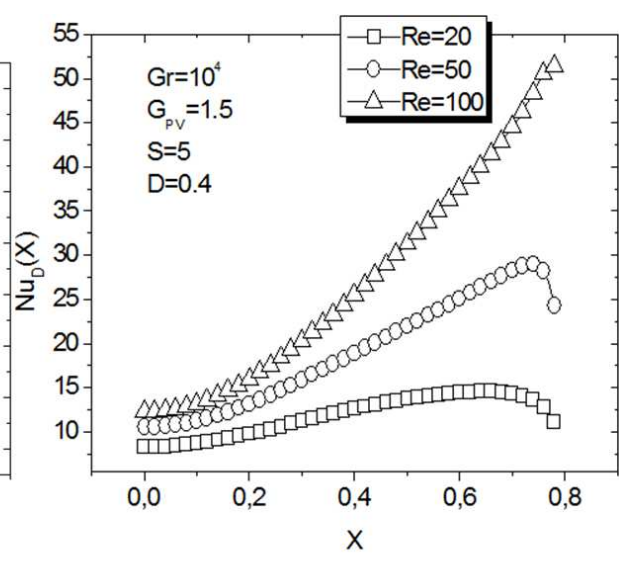

(b) upper horizontal wall

Figure 5. Variation of the local Nusselt number along the PV cells plate and the upper horizontal wall for various Reynolds numbers.

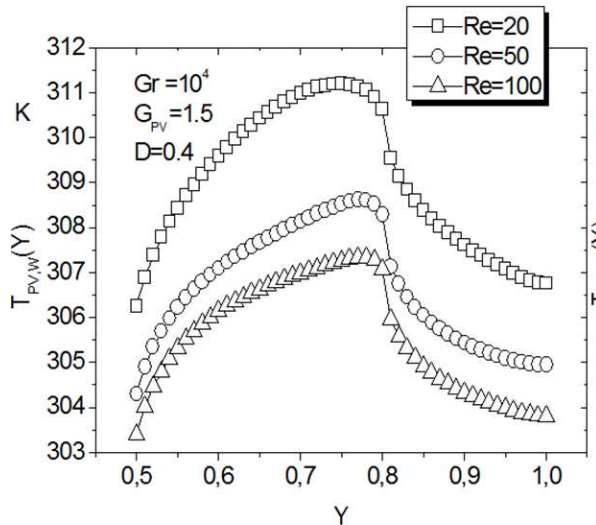

(a) PV cells plate and adiabatic wall

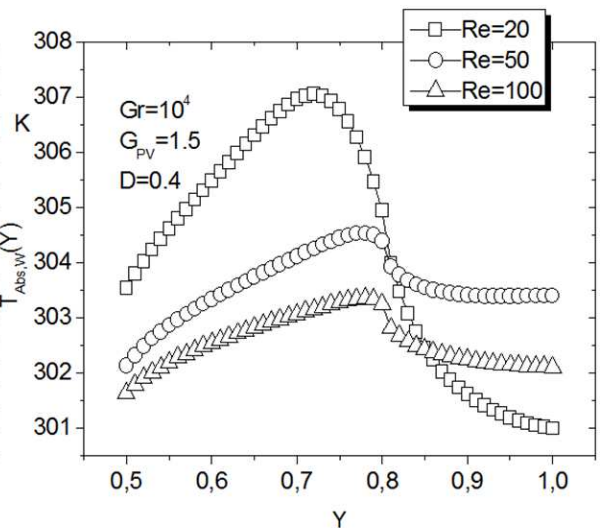

(b) Absorber plate and adiabatic wall

Figure 6. Distribution of the temperature along the plates of the integrated chimney for various Reynolds numbers.

Then the figure 6 shows that the temperature along the integrated chimney plates is a decreasing function when the Reynolds number is increasing.
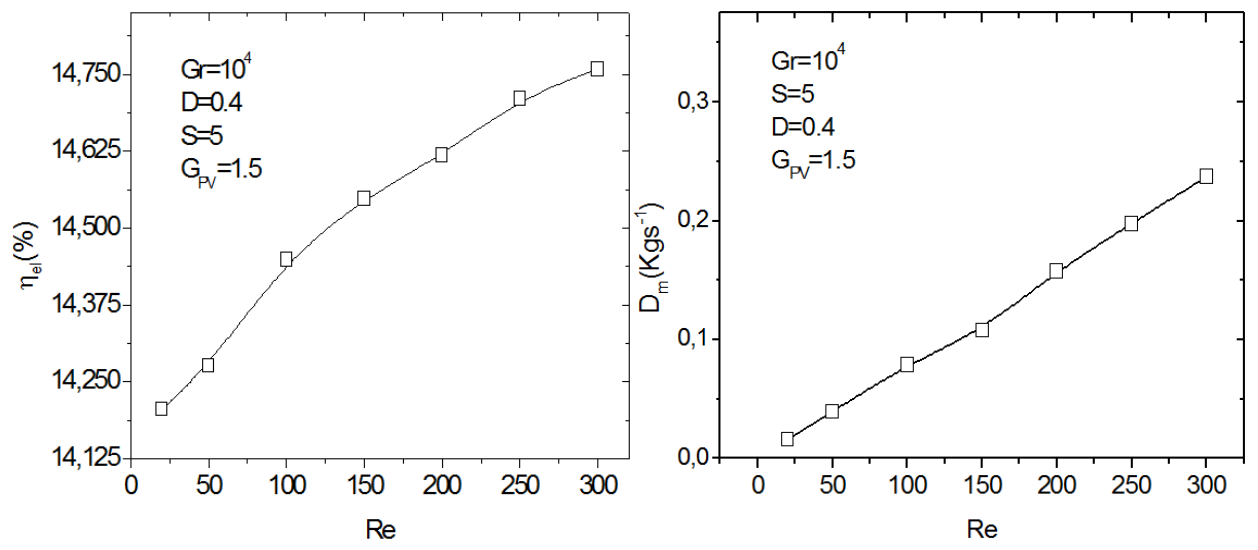

Figure 7. Solar cells PV electrical efficiency and mass flow rate versus Reynolds number.

This increase of Re contributes to the room ventilation by reducing the heated zones along the separated chimney plates and the upper horizontal heated wall. Consequentely the solar PV cells' efficiency or the mass flow rate is an increasing function of the Reynolds number, figure 7.

\subsection{Effect of Chimney Width (d)}

The width of the chimney plays an important role in flow 
generation; the figure 10 (a-b) shows that the local Nusselt number along the separated plates of the integrated chimney increases with an increase in width $d$. It means that when the width is greater, less is thermal transfer in the chimney.

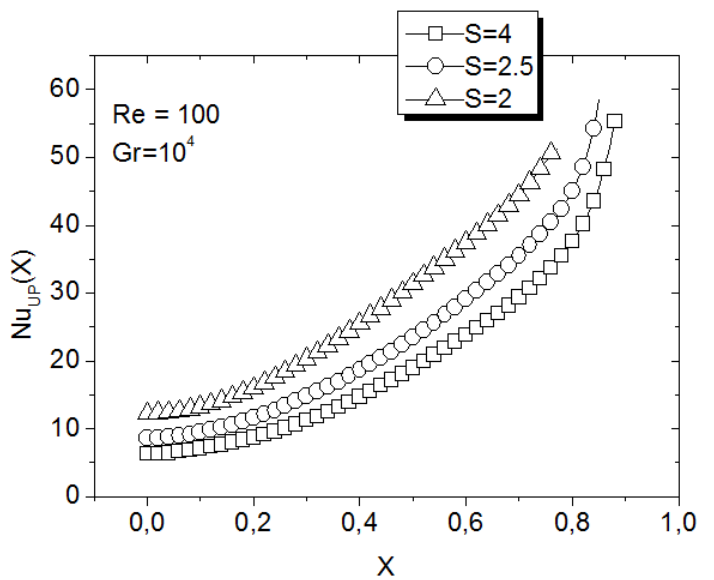

Figure 8. Variation in the local Nussselt number along the upper horizontal wall with the integrated chimney width.

The excess heat flux in the room and along the heated plates is not exchanged. In fact, the flow rate through the chimney increased with increasing the chimney width. The

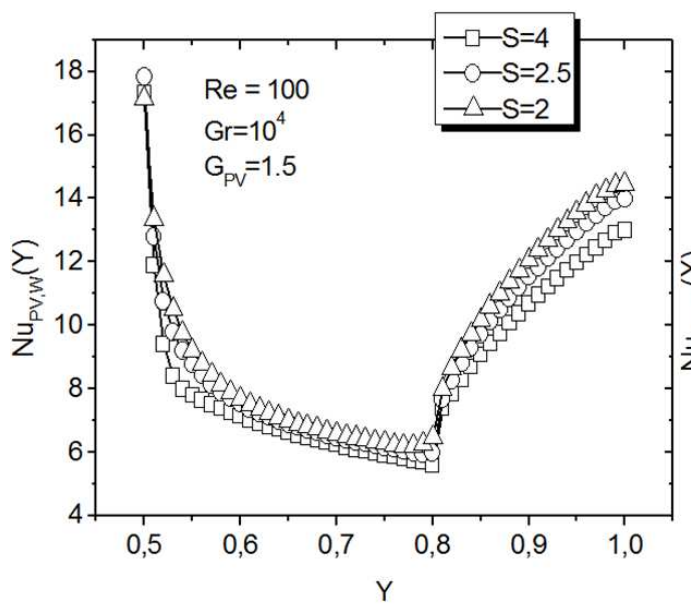

(a) PV cells plate and adiabatic wall same result is obtained by Sandberg et al. [27]. The distribution of the temperature gap along the separated plates of the integrated chimney shown in figure 9 indicates that the difference in temperature between the separated plates of the chimney is a decreasing function of the chimney width. The same variation is observed for the local Nusselt number along the upper horizontal heated wall, figure 8 .

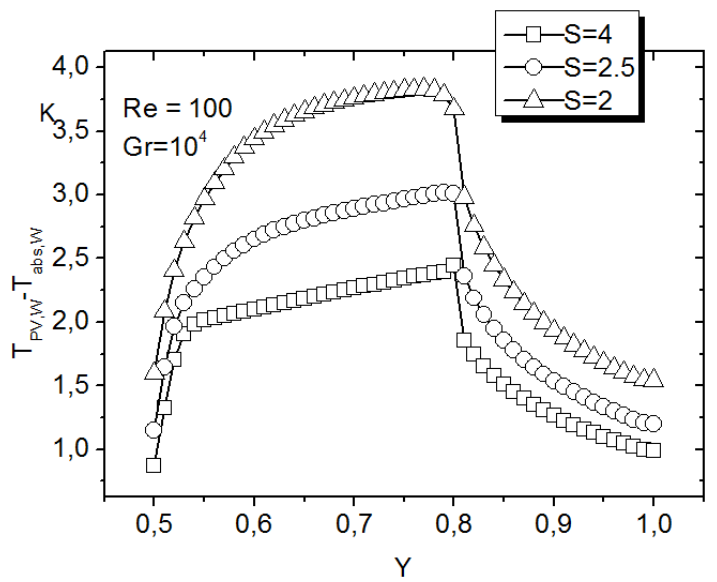

Figure 9. Distribution of temperature gap along the plates versus integrated chimney width.

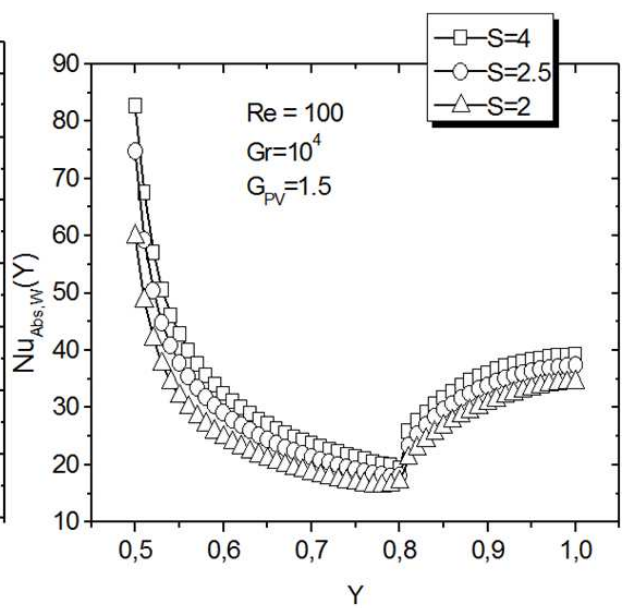

(b) absorber plate and adiabatic wall

Figure 10. Variation of the local Nusselt number along the integrated chimney plates with the separated width.

The length of the upper horizontal heated wall decreases when the chimney width d increases. Then the heated zone in the room disappears in favour of the cold zone, and the effectiveness cooling is obtained via the hybrid photovoltaicthermal integrated chimney into the building.

\subsection{Effect of Inlet Opening (e) Position}

The illustration in figure 11 shows that heat transfer decreases with the inlet opening position (e). This situation indicates that mass flow rate is a function of inlet opening position (e). These behaviour results from the fact that mixed convection is supported principally by the direct interaction between the open lines located near the heated plates in the chimney and the closed cells near the PV cells plate and the upper horizontal heated wall. The isotherm patterns plotted in the case $A_{0}=0$ indicate that the heat flux exchange is better in this configuration. The analysis of the streamlines reveals the existence of open lines superposed by trigonometric cells whose formation is rather due to a heating effect of coolant fluid and clockwise natural convection cells located under the permanently upper horizontal heated wall. It is assumed that the outlet velocity is an increasing function of the position of the inlet opening. 
$\mathrm{A}_{0}=0$

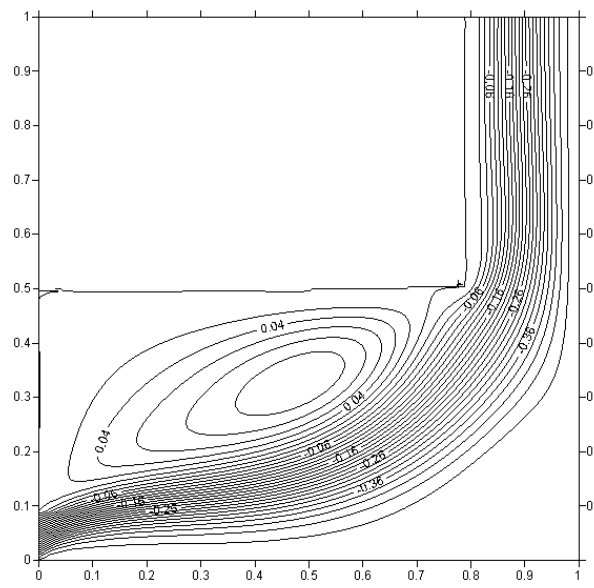

$\mathrm{A}_{0}=1.05$

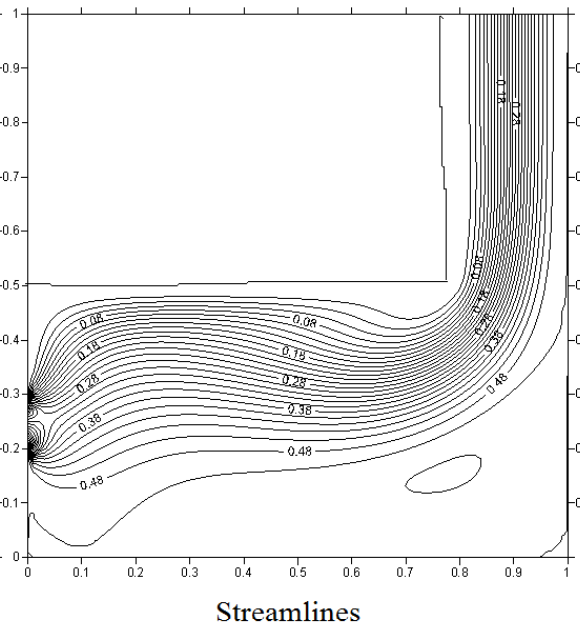

Streamlines
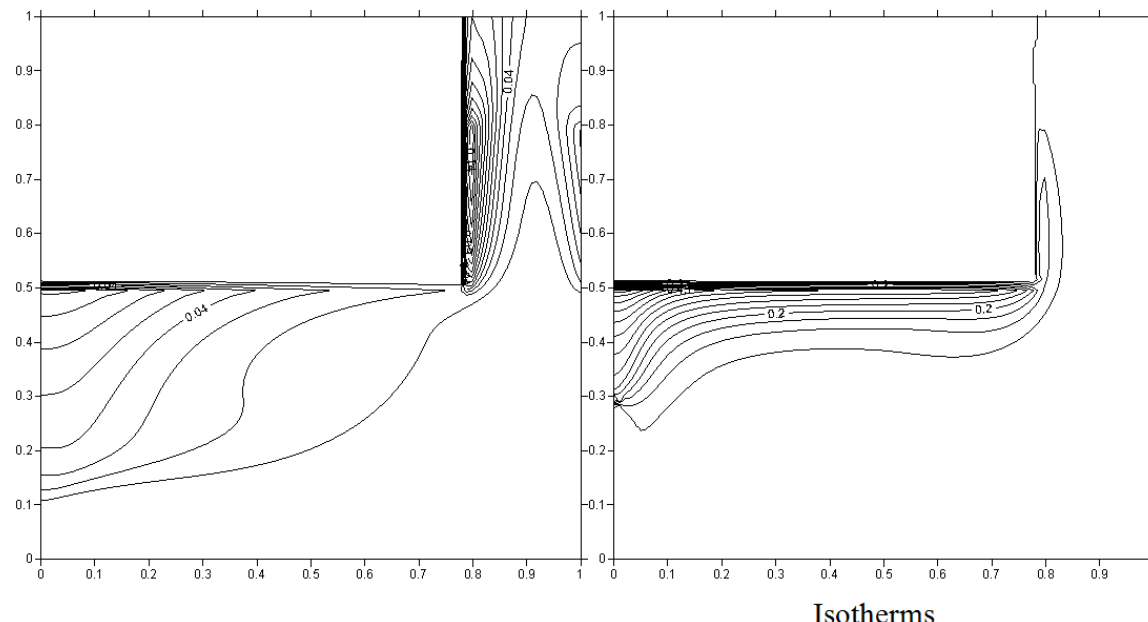

$\mathrm{A}_{0}=2.1$
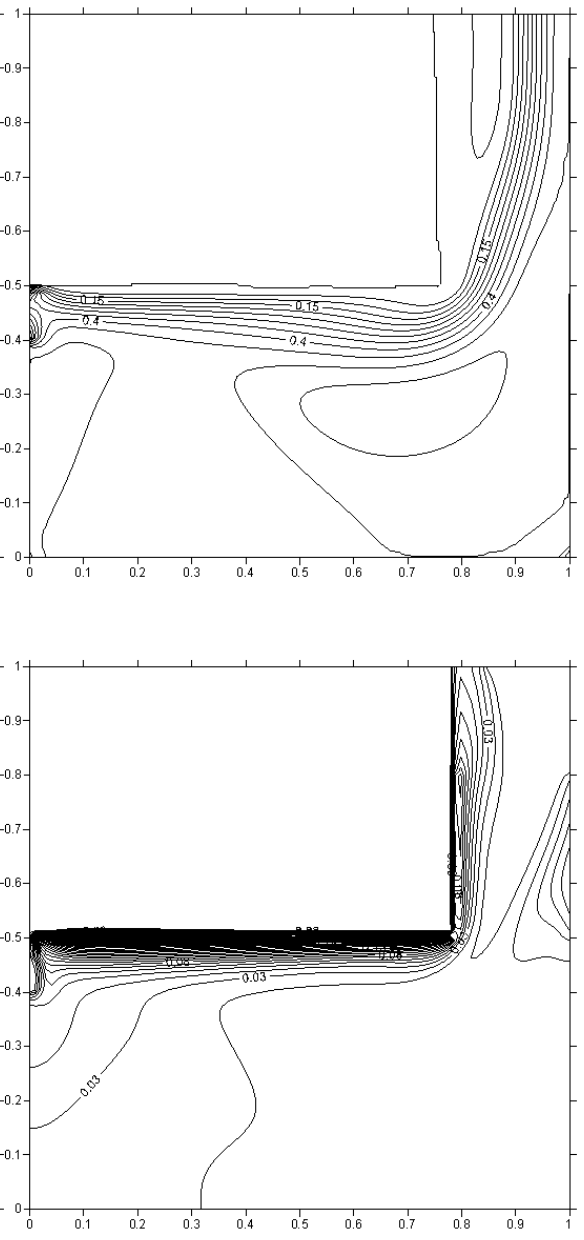

Figure 11. Streamline and isotherm patterns versus inlet opening position.

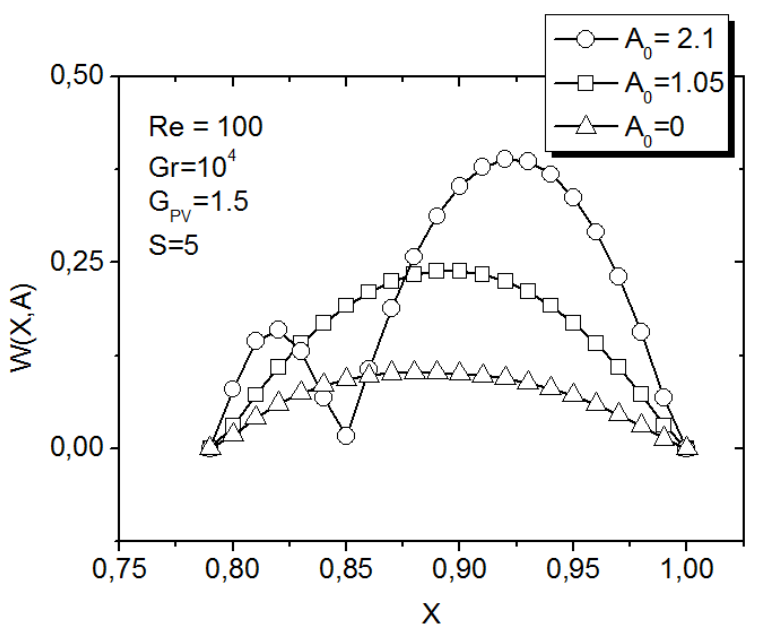

Figure 12. Variation in the outlet velocity for various inlet opening positions.

Figure 12 shows that the outlet velocity is higher in the case with a higher position of the inlet opening than the case of a smaller inlet opening position along the left vertical wall. Then the heat exchange process between a coolant fluid, the PV panel and the walls is very important in the case $\mathrm{A}_{0}=0$.
This situation is illustrated in figure 13 . For accessibility and aesthetic reasons, this configuration $\left(\mathrm{A}_{0}=0\right)$ is retained in this study. Then it is possible for providing the thermosiphon drawn of the air in the building via the integrated hybrid photovoltaic-thermal chimney.

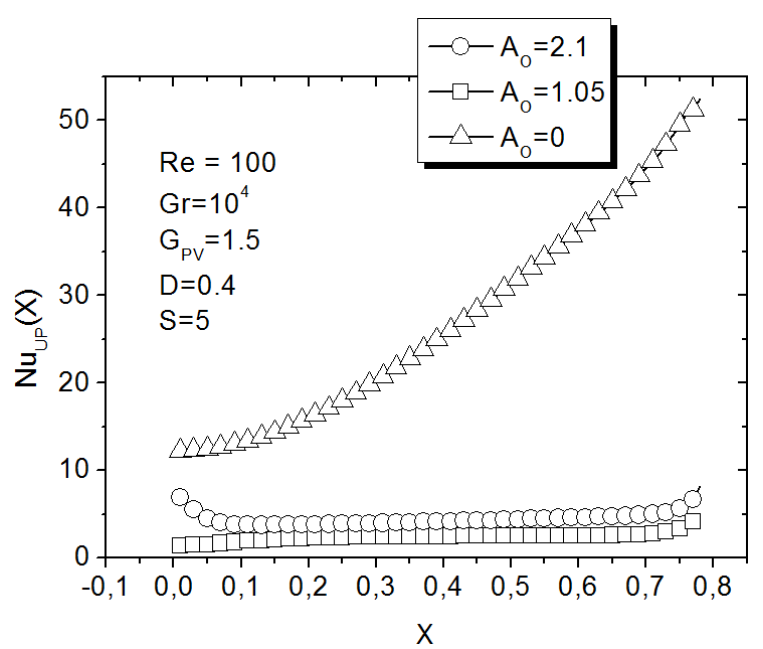

Figure 13. Variation in the local Nusselt number along the horizontal upper wall for various inlet opening positions. 


\subsection{Effect of PV Cells Plate Height $\left(h_{p v}\right)$}

The Local Nusselt number along the separated plates of the integrated chimney (PV cells plate and absorber plate connected to the adiabatic wall) decreases along the active walls when the ratio $h_{P V} / d$ increases, figure 15 . This figure indicates that heat exchange is an increasing function of the relative height of the solar PV cells plate location in the chimney.

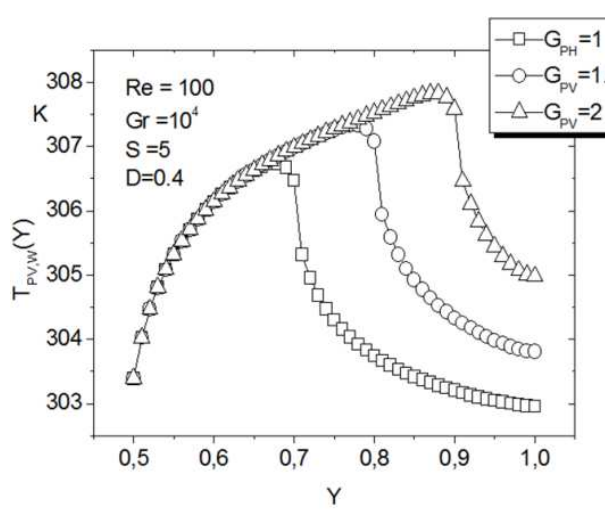

(a) PV cells plate and adiabatic wall

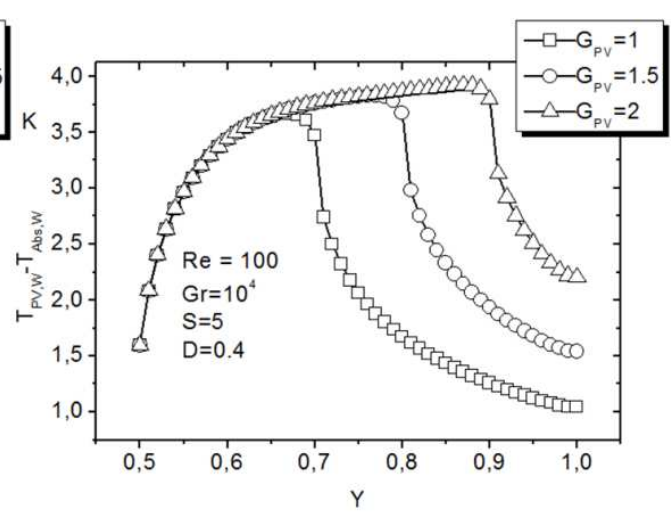

(b) Absorber plate and adiabatic wall

Figure 14. Plot of the temperature along the PV, the absorber and adiabatic walls along the integrated chimney against the relative PV plate height.

It is very clear that the best activity of heat transfer is obtained for the ratio $h_{P V} / d$ value equal to 2.0. This tendency is illustrated in figure $14(a-b)$, due consequentely, the higher $\mathrm{h}_{\mathrm{PV}} / \mathrm{d}$, the greater is the temperature difference between the separated plates along the integrated chimney. Consequentely, the cooling loads are marginally higher with the solar PV cells plate height locations studied, whereas the

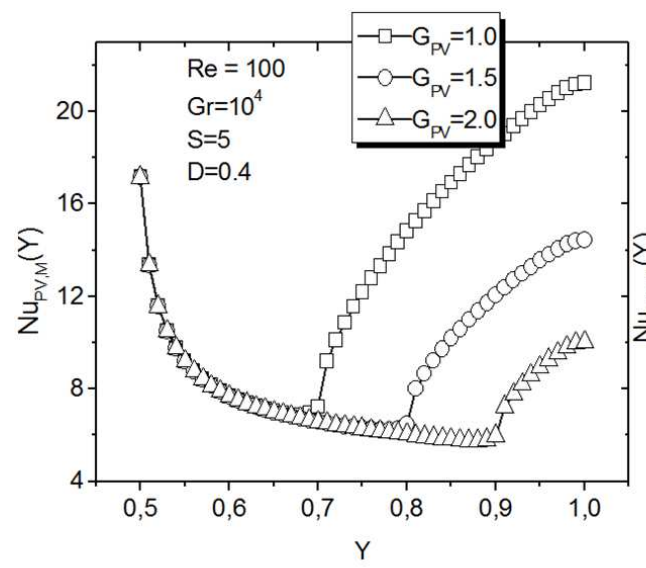

PV plate and adiabatic wall heating loads depend critically on PV cells plate location. Similar results are obtained by Mei et al [28] in the study of dynamic thermal simulation of a building with an integrated ventilated PV facade with TRNSYS. Figure 16 indicates that the local Nusselt number along the upper horizontal heated wall is an increasing function of the relative PV cells plate height $\left(\mathrm{h}_{\mathrm{PV}} / \mathrm{d}\right)$.

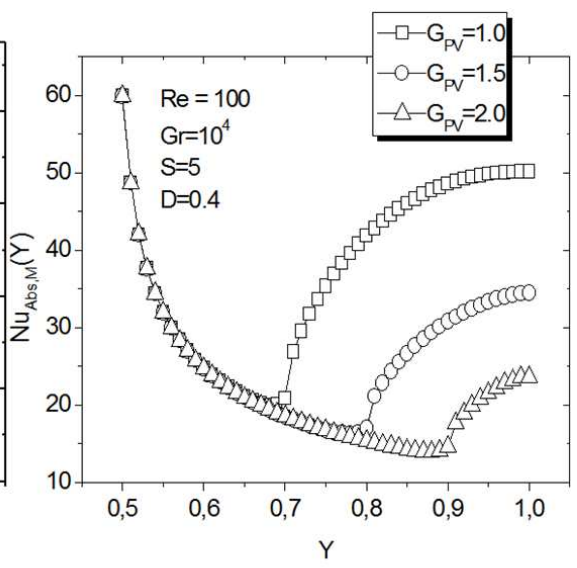

Absorber plate and adiabatic wall

Figure 15. Variation of local Nusselt number along the integrated chimney separated plates with PV cells plate height.

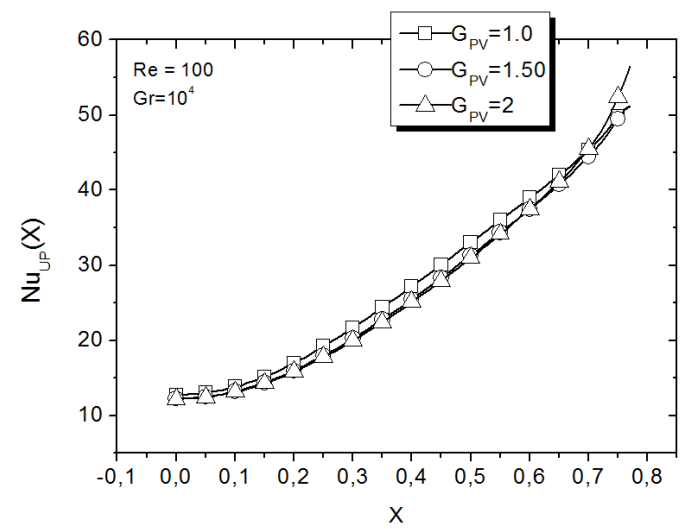

Figure 16. Variation of the local Nusselt number along the upper horizontal wall with the relative PV cells plate height. 


\subsection{Effect of Grashof Number}

The Grashof number is a very important control parameter for fluid flow in the ventilated enclosure. Thus figure 17 (a-c) shows that for $\mathrm{Gr} \leq 10^{3}$, two recirculation cells appear in the room. These closed cells are symmetrically separated by the forced flow open lines which extend into the integrated chimney.

$$
\mathrm{Re}=100, \mathrm{G}_{\mathrm{PV}}=1.5, \mathrm{~S}=5
$$

$\mathrm{Gr}=10^{3}$

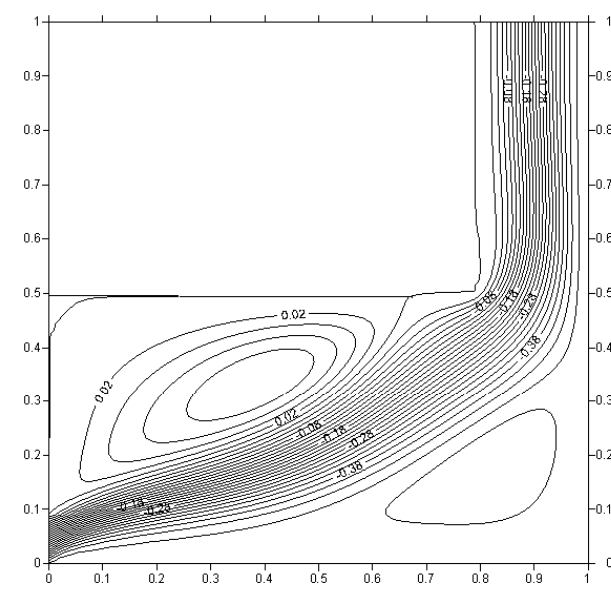

$\mathrm{Gr}=10^{5}$

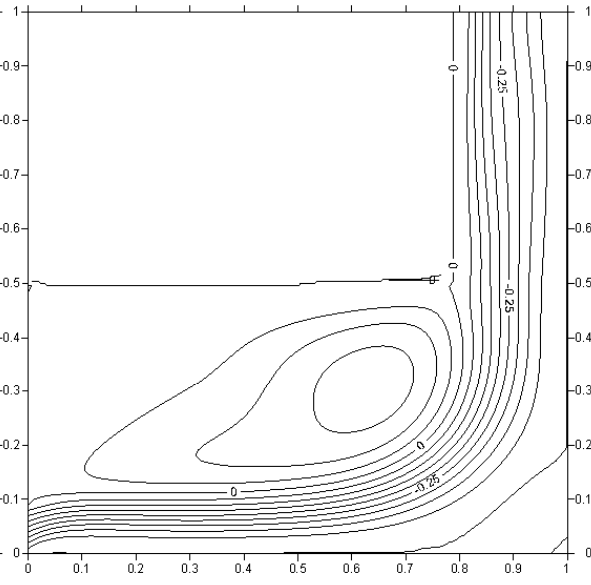

Streamlines

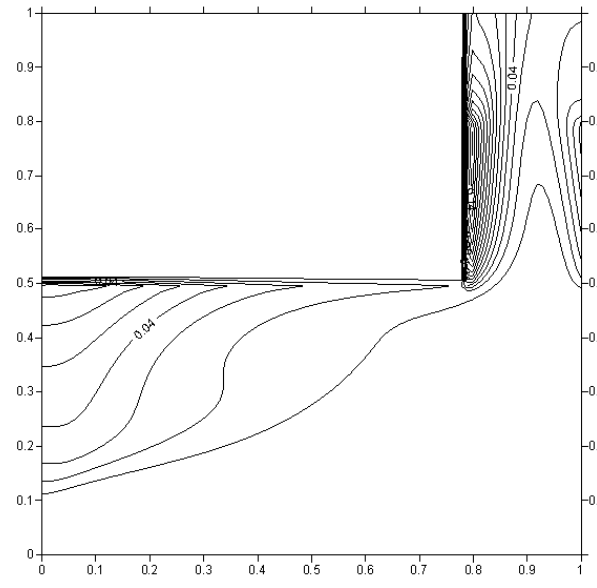

(a)

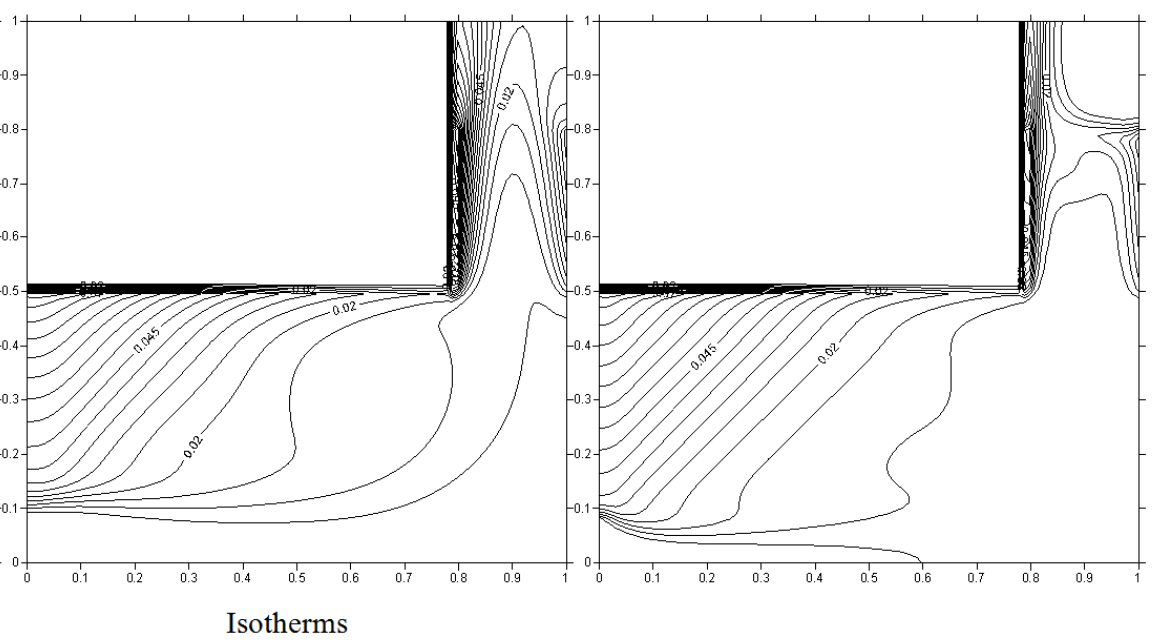

(b) (c)

Figure 17. Streamline and isotherm patterns versus the Grashof number.

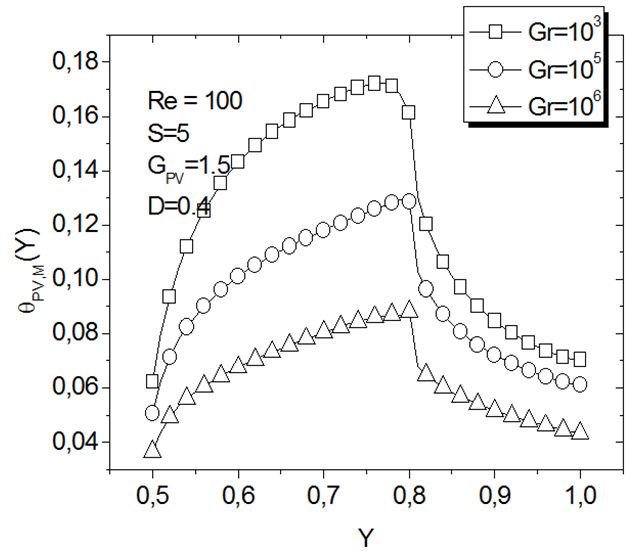

(a) PV cells plate and adiabatic wall

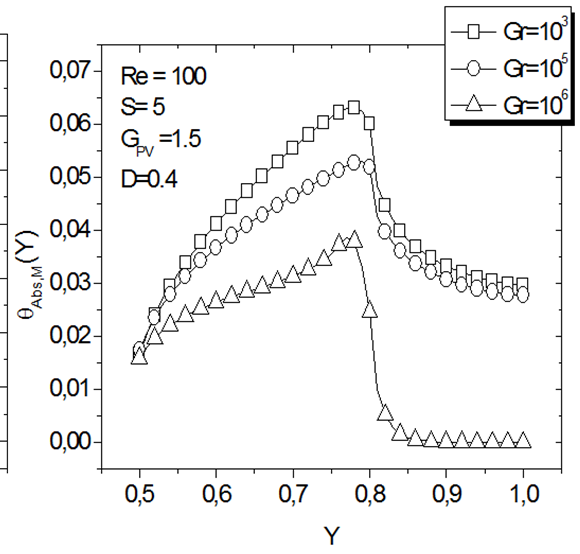

(b) Absorber plate and adiabatic wall

Figure 18. Variation in the dimensionless temperature along the PV and the adiabatic plates versus Grashof number. 
The upper recirculation cells become bigger when the Grashof number is increased to $10^{6}$ and prevent the fluid from cooling, and the lower natural convection closed cells disappear. For $\mathrm{Gr}=10^{6}$, the back flow phenomenon appears in the integrated chimney, consequentely thermal comfort disappears progressively in the room when the Grashof number increases. Because of the back flow phenomenon, the dimensionless temperature along the separated plates of the

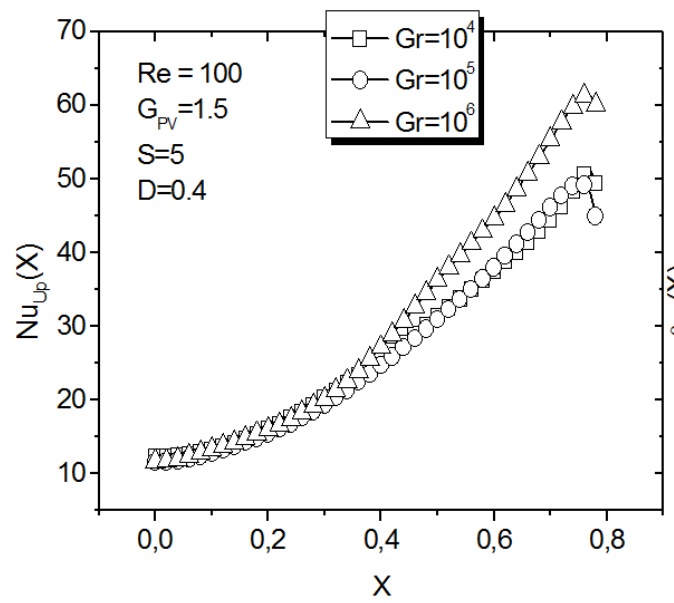

chimney decreases when the Grashof number increases, figure $18(a-b)$, it means that the dimensionless temperature is inversely proportional to the solar radiative heat flux by definition. In fact, Manca et al., [29] in their experimental investigation of natural convection in horizontal channels with the upper wall at uniform heat flux showed that when the Rayleigh number increases, the dimensionless temperature inside the cavity decreases.

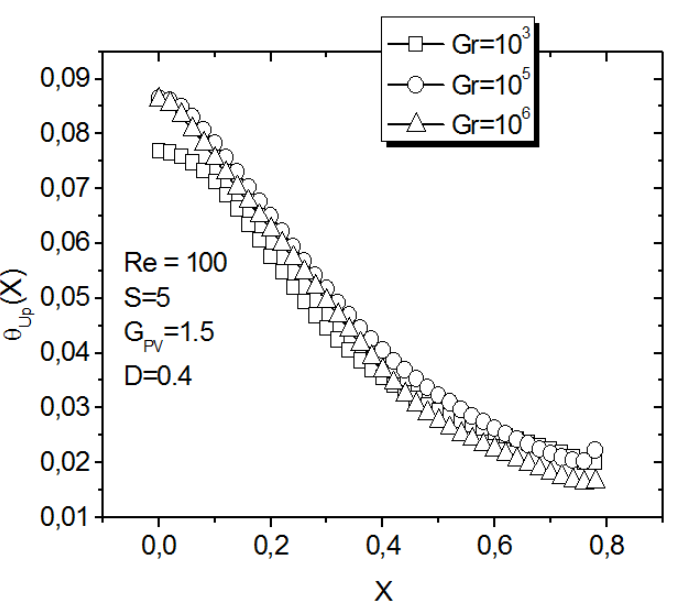

Figure 19. Variation of the local Nusselt number and the dimensionless temperature along the upper horizontal wall versus Grashof number.

The outlet velocity increases when the Grashof number increases, figure 20.

As the Grashof number increases, a thermal plume can be seen to be stratified from the upper horizontal heated wall to the room. If the Grashof number increases, the isotherms become more distorted in the integrated chimney.
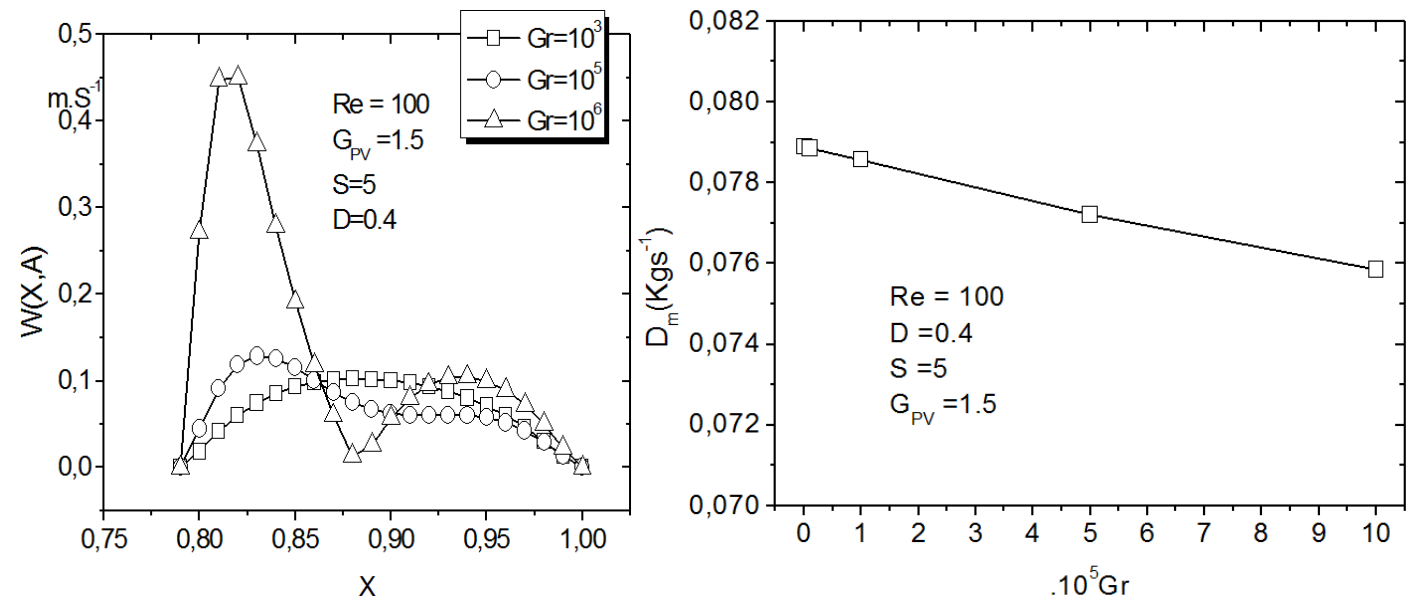

Figure 20. Variation of the outlet velocity and the mass flow rate with Grashof number.

The concentration of isotherms near the active walls, namely solar PV cells plate, the upper horizontal heated wall, and the absorber plate, indicate that the most of heat transfer takes place at the vicinity of the active walls. In fact, Bilgen et al. [30] in their study on an enclosure equipped with a chimney found that heat transfer and the Nusselt number are an increasing function of the Rayleigh number. The increase of Reynolds number or Grashof number leads to an increase in Nusselt number indicating an augmentation of the heat transfer rate. Figure 20 indicates that when the Grashof number increases, the mass flow rate decreases while outlet velocity increases to reach the maximal value before decreasing to attain the minimal value near the absorber plate.

\section{Conclusion}

A numerical investigation of laminar mixed convective cooling in a hybrid photovoltaic- thermal chimney integrated into a building has been conducted to identify the optimum placement of inlet and exit for the best cooling effectiveness. The study encompasses for ranging Grashof numbers $10^{3} \leq$ Gr $\leq 10^{6}$, Reynolds number from $20 \leq \operatorname{Re} \leq 200$ representing dominating forced convection through mixed convection to dominating natural convection. The local Nusselt number 
along the heated walls has been used to compare the cooling effectiveness in the integrated chimney.

The results indicated that:

a. Dimensionless temperature decreases with increasing Grashof and Reynolds numbers.

b. The local Nusselt number along the active plates of the integrated chimney is an increasing function of Reynolds and Grashof numbers.

c. Increasing the Reynolds number leads to a higher intensity of air flow for passive cooling, and the best electrical efficiency of the solar PV cells.

d. Possible reducing of cooling loads with the insertion of the photovoltaic cells plate into the chimney integrated into the building.

e. The flow rate through the integrated chimney increased with increasing chimney width.

Future work consists of integrating the hybrid photovoltaic channel in the roof for the thermal comfort in the buildings.

\section{Nomenclature}

Aspect ratio dimensionless of the global system $A=\frac{H}{d}$

Difference aspect ratio $A_{0}=\frac{\left(H_{1}-e\right)}{d}$

Specific heat $\left(\mathrm{J} \mathrm{kg}^{-1} \cdot \mathrm{K}^{-1}\right)$

Aspect ratio dimensionless of the inlet opening $D=\frac{e}{d}$

Channel width (m)

Relative length of the room after the inlet Opening $E=\frac{H_{1}}{d}$

Air inlet opening width (m)

Aspect ratio dimensionless of the height of the room $F=\frac{H_{1}}{d}$

Aspect ratio dimensionless of the height of PV cells plate $G_{P V}=\frac{H_{P V}}{d}$

Gravitational acceleration $\left(\mathrm{m} . \mathrm{s}^{-2}\right)$

Total height of the enclosure (m)

Aspect ratio dimensionless of the height of the upper adiabatic wall $J=\frac{H_{w}}{d}$

Aspect ratio dimensionless length of the room before the channel $K=\frac{L_{1}}{d}$

Total length of the enclosure $(\mathrm{m})$

Coordinate in normal direction

Nusselt number $N u=\frac{\varphi d}{\lambda\left(T-T_{a}\right)}$

Prandlt number $\operatorname{Pr}=\frac{\mu C p}{\lambda}$

Reynolds number $\operatorname{Re}=\frac{\rho u_{0} d}{\mu}$

Thermal Richardson number $R i=\frac{G r}{R_{e}^{2}}$

Aspect ratio dimensionless length of the room $S=\frac{L}{d}$

Time (s)

Temperature (K)

Ambient air temperature $(\mathrm{K})$

Velocity component in $\mathrm{x}$ and $\mathrm{y}$ directions $\left(\mathrm{m} . \mathrm{s}^{-1}\right)$

Dimensionless velocity component in $\mathrm{X}$ and $\mathrm{Y}$ directions; $U=\frac{u}{u_{0}}, V=\frac{v}{u_{0}}$

Air inlet velocity $\left(\mathrm{m} \cdot \mathrm{s}^{-1}\right)$

Dimensionless outlet velocity

Coordinates defined in figure $1(\mathrm{~m})$ 


$\begin{array}{ll}\mathrm{X}, \mathrm{Y} & \text { Dimensionless spatial coordinates; } X=\frac{x}{d} ; \\ & \text { Greek symbols } \\ \theta & \text { Dimensionless temperature } \theta=\frac{\lambda\left(T-T_{a}\right)}{\varphi d} \\ \tau & \text { Dimensionless time } \tau=\frac{u_{0} t}{d} \\ \beta & \text { Thermal expansion coefficient }\left(\mathrm{K}^{-1}\right) \\ \rho & \text { Density of the air }\left(\mathrm{kg} \cdot \mathrm{m}^{-3}\right) \\ \lambda & \text { Thermal diffusivity of the air }\left(\mathrm{W} \cdot \mathrm{m}^{-1} \cdot \mathrm{K}^{-1}\right) \\ \omega & \text { Dimensionless voticity } \omega=\frac{\Omega d}{u_{0}} \\ \mu & \text { Dynamic viscosity of the air }\left(\mathrm{kg} \cdot \mathrm{m}^{-1} \cdot \mathrm{s}^{-1}\right) \\ \Psi & \text { Dimensionless stream function } \Psi=\frac{\psi}{u_{0} d} \\ \varphi & \text { Solar radiation }\left(\mathrm{W} \cdot \mathrm{m}^{-2}\right) \\ \mathrm{PV} & \text { Subscripts } \\ \mathrm{w} & \text { PV module } \\ \mathrm{f} & \text { Wall } \\ \mathrm{Up} & \text { Fluid (air) } \\ & \text { Upper horizontal wall } \\ & \end{array}$

\section{References}

[1] Byrne P, Miriel J, Lenat Y (2012). Modelling and simulation of a heat pump for simultaneous heatingand cooling. Building Simulation, 5: PP 219-232.

[2] Nougblega, Ya. M. Banna, K. Napo, Thermal performances of hybrid photovoltaic/thermal collector designed for natural air updraught cooling into buildings in tropics, International Scientific Journal for Alternative Energy and Ecology № 11 (91) 2010, PP, 52-59.

[3] Hussain F., M. Y. H. Othman, K. Sopian, B. Yatim, H. Ruslan, H. Othman, Design development and performance evaluation of photovoltaic/thermal (PV/T) air base solar collector, Renewable and Sustainable Energy Reviews 25 (2013) 431441.

[4] Brinkworth, B. J., Cross, B. M., Marshall, R. H., and Yang, H. X. (1997) Thermal Regulation of Photovoltaic Cladding, Solar Energy, 61 (3), pp. 169-178.

[5] Yang, H. X., Marshall, R. H. and Brinkworth, B. J. (1996) Validated Simulation for Thermal Regulation of Photovoltaic Wall Structures, 25th PVSC, May 13-17, Washington, D. C., pp. 1453-1456.

[6] Raji, A., Hasnaoui, M., 1998a. Mixed convection heat transfer in a rectangular cavity ventilated and heated from the side. Numer. Heat Transer part A 33, PP 533, 548.

[7] Chen, Z. D., P. Bandopadhayay, J. Halldorsson, C. Byrjalsen, P. Heiselberg and Y. Li, 2003. An experimental investigation of solar chimney model with uniform wall heat flux. Building and Environment 38, pp. 893-906.

[8] Nougblega Ya., H. A. Samah, M. Banna K. Napo (2011). Numerical investigation of mixed convection from a heat generating PV cells in ventilated hybrid photovoltaic/thermal collector. International Scientific Journal for Alternative Energy and Ecology № 12 (92) 2010. PP 15-24.

[9] Santamouris M., Kolokotsa D. (2013). Passive cooling dissipation techniques for buildings and other structures: The state of the art. Energy and Buildings, 57: PP 74-94.

[10] Mohammad Sameti, Alibakhsh Kasaeian, (2015). Numerical simulation of combined solar passive heating and radiative cooling for a building, BUILD SIMUL (2015) 8: 239-253.

[11] Oosthuizen, P. H., Paul, J. T., 1985. Mixed convective heat transfer in a cavity. ASME HTD 42, PP 159-169.

[12] Raji, A., Hasnaoui, M., 1998b. Corrélations en convection mixte dans les cavités ventilées. Revue Générale de Thermique 37, PP 874-884.

[13] Raji, A., Hasnaoui, M., 2000. Mixed convection heat transfer in ventilated cavities with opposing and assisting flows. Eng. Comput. Int. J. Co mput. - Aided Eng. Softw. 17, PP 556-572.

[14] Manca, O., Nardini, S., Khanafer, K., Vafai, K., 2003. Effect of heated wall position on mixed convection in a channel with an open cavity. Numer. Heat Transfer part A 23, 463-484

[15] Singh, S. Sharif, M. A. R., 2003. 2003. Mixed convective cooling of a rectangular cavity with inlet and exit openings on differentially heated side walls. Numer. Heat transfer Part A 44, PP 223-253.

[16] Chan HY, Riffat SB, Zhu J (2010). Review of passive solar heating and cooling technologies. Renewable and Sustainable Energy Reviews, 14: PP 781-789.

[17] Hegazy A. A., Comparative study of the performances of four photovoltaic/thermal solar air collectors, Energy Conversion and Management 41 (2000) 861-881.

[18] Huang B. J., T. H. Lin, W. C. Hung, F. S. Sun, Performance evaluation of solar photovoltaic/thermal systems, Solar Energy 70 (5) (2001) 443-448. 
[19] Henning HM, Doll J (2012). Solar systems for heating and cooling of buildings. Energy Procedia, 30: PP 633-653.

[20] Mousavi S. S., and Hooman K. (2006). Heat and fluid flow in entrance region of a channel with staggered baffles. Energ Conversion and management 47, PP 2011-2019.

[21] Sameti M. (2014). Electrical energy efficient building through distributed generation. International Journal of Renewable Energy Research, 4: PP 777-783.

[22] Tripanagnostopoulos, Y. T. H.. Nousia, M. Souliotis, P. Yianoulis, Hybrid photovoltaic/thermal solar systems, Solar Energy 72 (3) (2002) 217-234.

[23] Bergene, T., O. Lovik, Model calculations on a flat-plate solar heat collector with integrated solar cells, Solar Energy 55 (6) (1995) 453-462.

[24] Krauter S., R. Hanitshch. Actual optical and thermal performance of PV-modules Solar Energy materials and Solar Cells 41-42, (1996). PP 557-574.

[25] Woods L. C., A note of numerical solution of fourth differential equations, Aero. Q. 5 (1954) 176-184.
[26] Wam, D. C., B. S. U. Patmaik and G. W. Wei (2001). A new benchmark quality solution for the buoyancy driven cavity by discrete singular convolution. Numerical Heat Transfert, Part B. 40. PP 199-228.

[27] Sandberg M., Mosfegh, B. (1996b). Investigation of fluid flow and Heat Transfer in a Vertical Channel heated from one side by PV elements, part 1. Numerical study, Renewable Energy, PP. 248-53.

[28] Mei, L. David Infield, Eicker, U, Fuxv. (2002). Thermal modeling of a building with an integrated ventilated PV façade. Energy and Buildings, Vol. 35, PP 605-617.

[29] Manca O., S. Nardini, (2007). Experimental investigation on natural convection in horizontal channels with the upper wall at uniform heat flux. International Journal of heat and mass Transfer, Vol. 50, pp. 1075-1086.

[30] Bilgen, E., T. Yamane, conjugate heat transfer in enclosures with openings for ventilation. Heat and Mass Transfer, Vol. 40, pp. 401-4011, 2004. 